\title{
ANALISA PENGARUH PELATIHAN MEDIA PEMBELAJARAN ONLINE PADA GURU SEKOLAH DASAR NEGERI 2 KAWAN BANGLI
}

\author{
Ni Ketut Utami Nilawati \\ STMIK STIKOM Indonesia, Denpasar, Indonesia \\ e-mail: utami.nilawati@stiki-indonesia.ac.id \\ Ayu Manik Dirgayusari \\ STMIK STIKOM Indonesia, Denpasar, Indonesia \\ e-mail: ayu.manik@stiki-indonesia.ac.id \\ I Kadek Dwi Gandika Supartha \\ STMIK STIKOM Indonesia, Denpasar, Indonesia \\ e-mail: gandika.supartha@stiki-indonesia.ac.id \\ Dewa Putu Yudhi Ardiana \\ STMIK STIKOM Indonesia, Denpasar, Indonesia \\ e-mail: dewayudhi@stiki-indonesia.ac.id \\ I Gde Eka Dharsika \\ STMIK STIKOM Indonesia, Denpasar, Indonesia \\ e-mail: ekadharsika@stiki-indonesia.ac.id
}

\begin{abstract}
With the current outbreak of the corona virus, all sectors must start to improve so that they can survive during a pandemic, including the education sector. The teaching and learning process carried out during a pandemic situation like this is carried out using an online system and distance learning. Teachers must be able to provide facilities so that students can absorb the material optimally. Another problem that arises is that not all teachers are able to implement the distance learning system and also using the applications or technologies that support distance learning system. To solve this problem, the school needs to get the training of how to make a distance learning system media and in this case the school cooperates with STMIK STIKOM INDONESIA (STIKI) for the training. The training materials provided are google classroom training, google form and training on making the learning videos. The results of the analysis were obtained from the pretest and posttest questionnaires which were described descriptively. After receiving the training, most of the teachers will switch to use the Google Classroom media instead of WA social media, because $100 \%$ of the teachers stated that Google Classroom is very helpful in supporting online learning. In addition, according to the posttest questionnaires, $8.3 \%$ of the teachers understand very well about the features contained in Google Classroom, $41.7 \%$ understand it well and $50 \%$ are understand it quite well, meaning that most of the teachers understand the use of Google Classroom. The training also received a good responses from SDN 2 Kawan School and it will be applied to support their distance learning system.
\end{abstract}

Keywords-Google Classroom, distance learning, online 


\section{PENDAHULUAN}

Dalam proses pembelajaran, penggunaan media pembelajaran merupakan salah satu faktor penentu keberhasilan pembelajar dalam menguasai materi pembelajaran. Media pembelajaran yang sedang digalakkan penggunaannya di Indonesia adalah media berbasis teknologi informasi. SD Negeri 2 Kawan adalah satu SD Negeri yang ada di Kecamatan Bangli, Kabupaten Bangli, Bali.

SD Negeri 2 Kawan adalah salah satu sekolah dasar negeri di kecamaan Bangli, Kabupaten Bangli, Bali. Sekolah ini berdiri di lahan seluas $2020 \mathrm{~m}^{2}$, dimana memiliki ruangan kelas sebanyak 12 rombel. Sekolah ini memiliki guru sebanyak 18 orang yang berstatus PNS sebanyak 9 orang dan yang berstatus guru honorer sebanyak 9 orang sedangkan jumlah siswa sebanyak 304 untuk kelas 1 sampai dengan kelas 6 .

Selama ini sistem pembelajaran dilakukan dengan cara guru bertatap muka dengan siswa dimana setiap hari materi yang diajarkan disesuaikan dengan jadwal dan sub pokok bahasan sesuai dengan kurikulum yang ada. Sekolah selama ini dalam setiap proses belajar mengajarnya hanya menggunakan fasilitas yang ada di sekolah dan masih sangat minim penggunaan teknologi informasi dan belum ada inovasi dalam pengembangan media pembelajaran. Pengajaran adalah suatu aktivitas (proses) mengajar belajar yang di dalamnya ada dua subyek, yaitu guru dan peserta didik Tugas dan tanggung jawab utama seorang guru adalah mengelola pembelajaran dengan lebih efektif. Pengajaran bukan konsep atau praktik yang sederhana, tetapi bersifat kompleks, dengan kata lain tugas mengajar adalah berat, kompleks perlu keseriusan tidak cobacoba dan asal jadi, pengajaran bukan konsep atau praktek.(Minardi and Akbar, 2020)

Dengan mewabahnya virus corona seperti saat ini, semua sektor harus mulai berbenah agar bisa bertahan ditengah pandemi termasuk dunia pendidikan. Proses belajar mengajar yang dilakukan di tengah situsi pandemi seperti ini dilakukan dengan sistem daring dan pembelajaran jarak jauh. Guru harus mampu menyediakan sarana agar peserta didik dapat menyerap materi dengan maksimal. Saat ini sudah banyak fasilitas berbasis teknologi infomasi berupa aplikasi yang dapat digunakan, baik berbayar ataupun tidak. Handayani (2021) misalnya mengajarkan metode dengan media social selama masa pandemic dalam proses pembelajaran. Masalah lain yang muncul adalah tidak semua guru mampu untuk menerapkan sistem pembelajaran jarak jauh (PJJ) dan dengan penggunaan aplikasi atau teknologi yang ada.

Untuk menyelesaikan masalah tersebut maka pihak sekolah SDN 2 Kawan yaitu melakukan pelatihan pengunaan media untuk pembelajaran secara online. Tujuan dari pelatihan ini adalah untuk memberikan sudut pandang dan pemahaman yang lebih baik tentang pembelajaran secara online serta meningkatkan kreatifitas guru SDN 2 Kawan untuk membuat bahan ajar pembelajaran jarak jauh ini. Selain itu hasil dari kegiatan ini akan dianalisa seberapa besar pengaruh pelatihan ini bagi guru SDN 2 Kawan.

\section{METODE}

Berdasarkan penjelasan diatas maka dapat disimpulkan bahwa SDN 2 Kawan memiliki kendala dalam menjalankan pembelajaran jarak jauh terutama dalam pemanfaatan teknologi informasi adalah sebagai berikut:

1. Tenaga pendidik sebagian besar belum mengetahui teknologi yang dapat digunakan untuk mempermudah sistem pembelajaran jarak jauh atau secara online (daring). 
2. Tenaga pendidik belum pernah menggunakan atau mendapatkan pelatihan tentang pemanfaatan software untuk mendukung sistem pembelajaran jarak jauh atau online.

3. Kurangnya pengetahuan tenaga pendidik untuk memperlancar proses pembelajaran jarak jauh atau online.

4. Kurangnya pemahaman siswa terhadap materi yang dibagikan oleh tenaga pendidik yaitu dalam hal ini guru karena materi yang dibagikan kurang menarik, kurang bervariasi dan kurang mengikuti perkembangan teknologi yang ada.

Sehingga dari permasalahan yang telah dijabarkan maka salah satu solusi yang dapat ditawarkan adalah pelatihan online yang meliputi pelatihan pemanfaatan google classroom sebagai sarana PJJ, pelatihan pembuatan kuis yang lebih mudah menggunakan google form pada google classroom dan pelatihan pembuatan video pembelajaran untuk materi pengajaran yang lebih menarik. Adapun skema kegiatan yang akan dilakukan pada pelatihan ini dapat dlihat pada gambar 1.

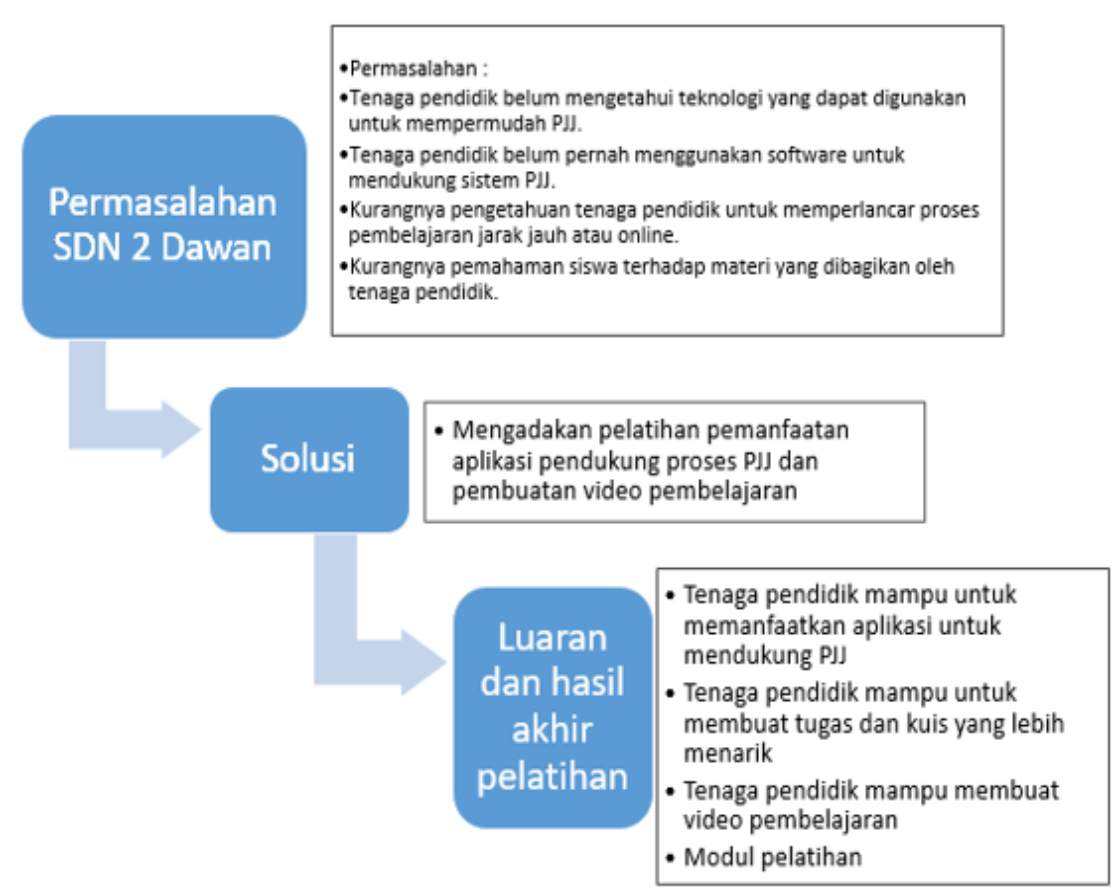

Gambar 1. Skema Kegiatan Pengabdian

\section{HASIL DAN PEMBAHASAN}

Pelaksanaan kegiatan pengabdian ini terdiri dari observasi, perencanaan, pelaksaan dan evaluasi.

1. Observasi

Pada tahap awal adalah yaitu dilakukan proses observasi yaitu datang langsung ke sekolah SDN 2 Kawan untuk berdiskusi untuk kegiatan pelatihan yang akan dilakukan. Selain itu membicarakan hal-hal yang harus dikerjakan untuk terciptanya pelatihan yang baik dan lancar.

2. Perencanaan

Proses perencanaan disini meliputi :

a. Melakukan diskusi dengan pihak sekolah untuk menetapkan tanggal kegiatan dan mekanisme pelaksanaan pelatihan 
b. Merancang materi yang akan disampaikan pada setiap sesi pelatihan

c. Sosialisasi rencana kegiatan pelatihan kepada kepala sekolah dan guruguru

d. Membentuk panitia dan pembagian tugas

3. Pelaksanaan

a. Sebelum kegiatan pelatihan dimulai, setiap peserta akan mengisi Pretest untuk mengetahui kemampuan peserta pelatihan sebelum diberikan pelatihan dan sesudah diberikan pelatihan. Selain itu dilakukan juga pengisian posttest oleh peserta dimana tujuannya adalah untuk mengetahui seberapa besar pemahama peserta dalam penyerapan materi pelatihan.

b. Pelatihan penggunaan Google Classroom untuk membantu kegiatan belajar mengajar secara daring/online.

c. Pelatihan penggunaan Google Form yaitu untuk membantu guru dalam membuat tugas, latihan ataupun ujian.

d. Pelatihan pembuatan video pembelajaran dengan aplikasi Format Factory.

4. Evaluasi

Proses evaluasi dilakukan untuk mengetahui kekurangan dan kendala dalam pelaksanaan kegiatan pelatihan.

Kegiatan pelatihan untuk guru di Sekolah Negeri 2 Kawan dilaksanakan dalam tiga sesi pelatihan, yaitu:

1. Sesi 1 Materi Google Classroom

Untuk pelatihan materi google classroom dilaksanakan diawali dengan penjelasan singkat tentang materi google classroom dan cara menggunakannya. Setelah itu guru-guru langsung diarahkan untuk mencoba sendiri dan didampingi oleh pendamping. Diharapkan dengan cara praktek langsung peserta pelatihan dapat menemukan sendiri masalah yang ada dan bisa langsung menanyakan jika terdapat kesulitan. Untuk dokumentasi pada saat pelatihan materi google classroom dapat dilihat pada Gambar 2.

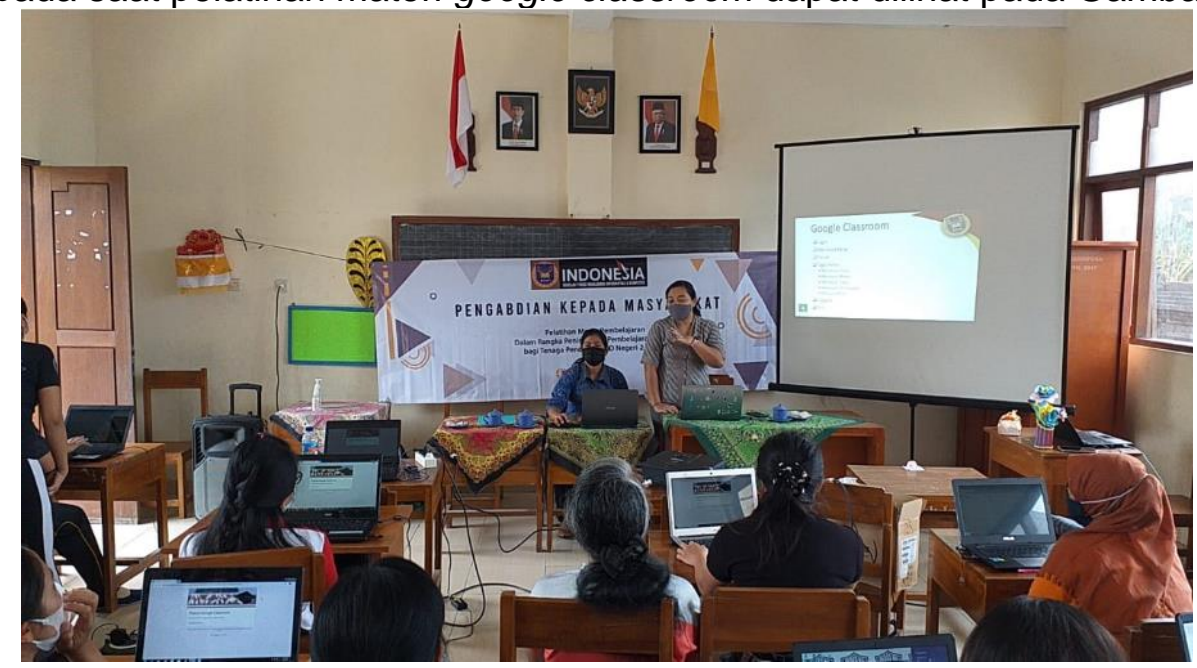

Gambar 2. Dokumentasi Pelatihan Materi Google Classroom

2. Sesi 2 Materi Google Form

Setelah mendapat pelatihan tentang google classroom selanjutnya yaitu pelatihan google form. Pelatihan ini diberikan sebagai lebih memantapkan lagi penggunaan materi pada google classroom terutama dalam memberikan tugas, latihan, ulangan harian dan ujian para siswa. 
Pemanfaatan google form sangat membantu dalam membuat tugas, latihan, ulangan harian dan ujian. Untuk dokumentasi pada saat pelatihan materi google form dan google drive dapat dilihat pada Gambar 3 di bawah ini:

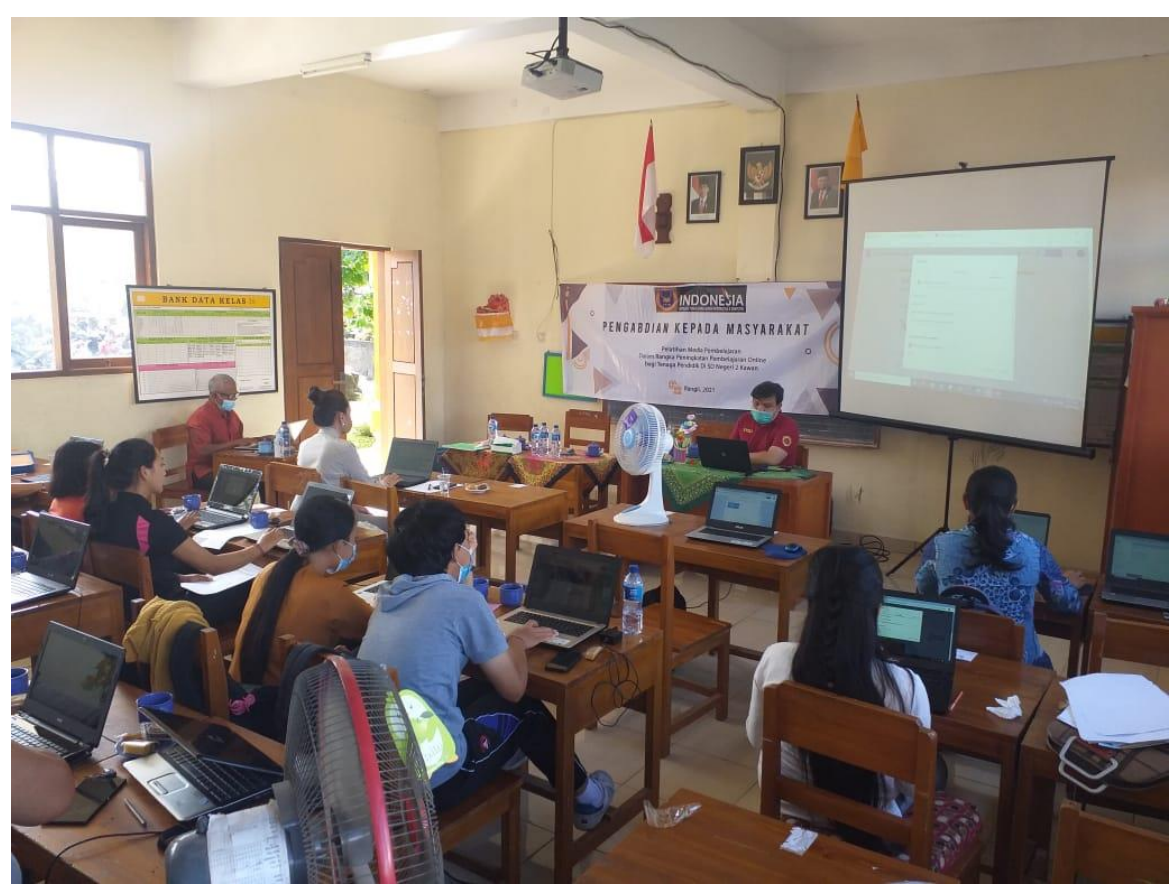

Gambar 3. Dokumentasi Pelatihan Materi Google Form

3. Sesi 3 Materi Pembuatan Video Pembelajaran

Setelah peserta cukup menguasai materi google classroom dan google form selanjutnya diberikan pelatihan pembuatan video pembelajaran. Pelatihan ini bertujuan untuk meningkatkan kemampuan para peserta didalam membuat materi pembelajaran, karena dengan kondisi pandemi seperti saat ini pembelajaran masih dilakukan dengan daring. Jika materi yang diberikan masih konvensional, para siswa tentu akan merasa bosan dan agak sulit untuk memahami materi yang diberikan. Jadi salah satu solusinya adalah memberikan materi dalam bentuk video. Belajar dengan materi yang dilengkapi dengan video memiliki kelebihan lebih mudah untuk dimengerti dan lebih menarik. Materi pembuatan video pembelajaran menggunakan aplikasi Format Factory, yaitu salah satu aplikasi yang sederhana dan mudah dalam penggunaannya. Selain itu aplikasi ini dapat diunduh secara gratis. Untuk dokumentasi pada saat pelatihan materi video pembelajaran dapat dilihat pada Gambar 4 di bawah ini: 


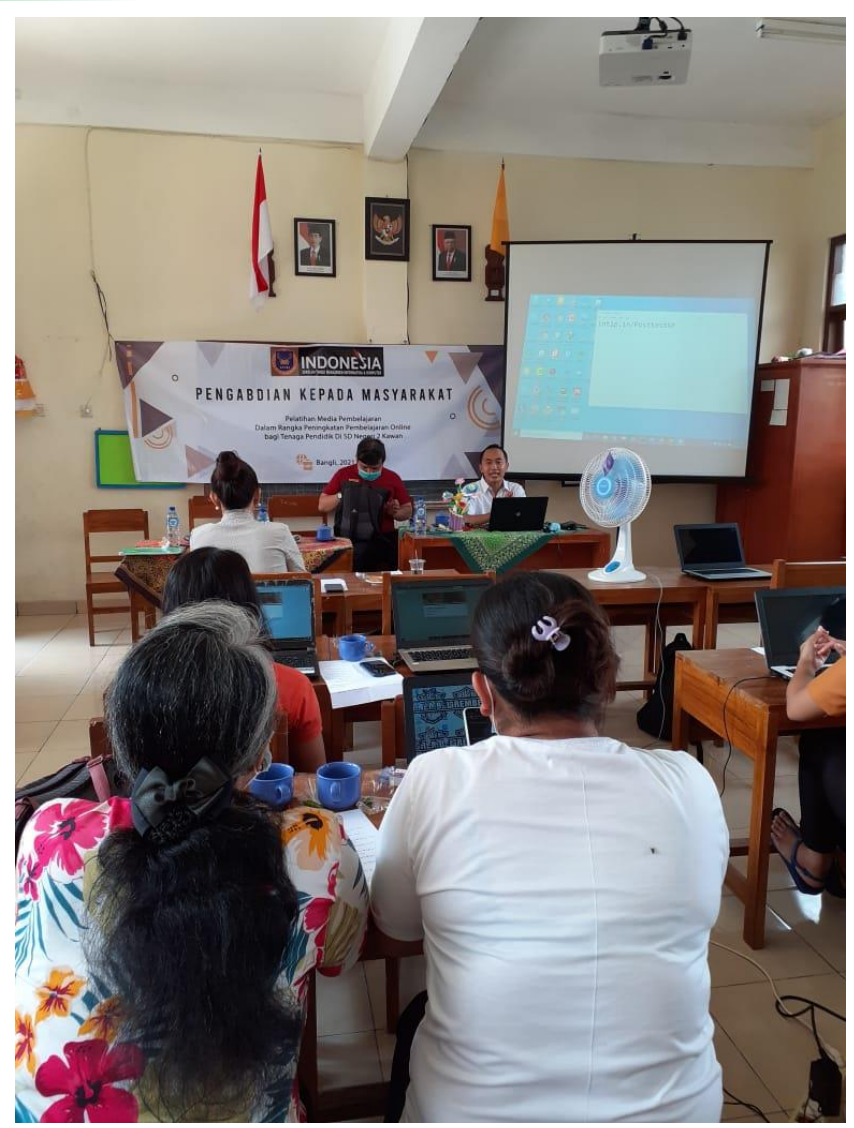

Gambar 4. Dokumentasi Pelatihan Materi Video Pembelajaran

Pada setiap kegiatan pelatihan yang dilakukan baik materi google classroom, google form dan pembuatan video pembelajaran, adapun langkahlangkah pelaksanaan pelatihannya yaitu :

1. Sesaat sebelum pelatihan mulai dilakukan guru-guru diminta mengisi pretest, tujuan mengisi pretest adalah untuk mengetahui kemampuan dasar yang telah dimiliki oleh guru mengenai materi yang akan diberikan. Hal ini cukup penting karena dengan mengetahui kemampuan awal dari peserta maka dapat menyesuaikan dengan materi yang akan diberikan.

2. Pelatihan dilakukan secara langsung dimana, pemateri menjelaskan setiap materi dengan detail sesuai dengan materi yang diajarkan. Setiap materi yaitu Google Classroom, Google Form dan Format Factory dijelaskan oleh 1 orang pemateri, jadi pada kegiatan PKM ini terdapat 3 pemateri.

3. Pada setiap pelatihan, para pemateri akan memberikan penjelasan terlebih dahulu, setelah materi selesai diberikan maka para guru akan langsung mencoba materi yang diajarkan. Pada saat para guru mencoba materi yang sudah diajarkan, guru juga dapat bertanya dan berdiskusi terkait materi yang di coba. Pada saat para guru mempraktekkan apa yang diajarkan, para guru akan didampingi oleh fasilitator sehingga kegiatan praktek akan berjalan lebih lancar.

4. Setiap guru dapat mencoba materi yang diajarkan lebih detail, misalnya pada saat mencoba untuk mempraktekkan google classroom setiap guru dapat mencoba membuat kelas dan materi sesuai dengan kelas guru tersebut ajarkan. Atau pada saat materi google form guru dapat membuat tugas, latihan dan ujian sesuai dengan kelas yang guru tersebut ajarkan. 
5. Pengisian posttest dilakukan setelah pelatihan, diskusi dan praktek langsung. Tujuan posttest ini untuk mengetahui apakah materi yang telah diberikan sudah dapat membantu guru-guru dalam melaksanakan kegiatan pembelajaran secara daring dan untuk mengetahui tingkat keberhasilan dari kegiatan pelatihan yang telah dilakukan.

\subsection{Pembahasan Hasil Pelatihan}

Untuk mengetahui hasil dari pelatihan yang telah dilakukan maka harus dilakukan analisis terhadap respon dari peserta pelatihan. Metode yang digunakan yaitu penelitian deskriptif. Metode penelitian deskriptif adalah penelitian yang dilakukan dengan menjelaskan atau menggambarkan variablel yang sedang diteliti. Penelitian deskriptif berkaitan dengan pengkajian fenomena secara lebih rinci atau membedakannya dengan fenomena yang lain (Siyoto and Sodik, 2015). Tujuan dari penelitian diskriptif yaitu menjelaskan, meringkas berbagai kondisi (Bungin. 2011).

Pengambilan data dan sampel digunakan pretest dan posttest sebagai angket. Pretest diberikan adalah sebagai angket untuk mengetahui pemahaman para guru tentang google classroom yang mereka pahami. Sedangkan untuk posttest yaitu angket untuk mengetahui seberapa jauh pemahaman para guru setelah mendapat pelatihan tentang google classroom. Pada tabel 1 merupakan pertanyaan yang digunakan untuk mengukur tingkat perkembangan guru sebelum memperoleh pelatihan.

Tabel 1. Tabel pertanyaan pretest

\begin{tabular}{|c|l|}
\hline No. & \multicolumn{1}{|c|}{ Pertanyaan } \\
\hline 1. & $\begin{array}{l}\text { Apakah Anda merupakan tenaga pengajar (Guru) yang saat ini } \\
\text { sedang aktif menjadi Guru pengampu mata pelajaran? }\end{array}$ \\
\hline 2. & $\begin{array}{l}\text { Di masa pandemi ini, apakah Anda memberikan pengajaran kepada } \\
\text { siswa/siswi secara online/jarak jauh/sekolah dari rumah? }\end{array}$ \\
\hline 3. & $\begin{array}{l}\text { Dari pilihan di bawah ini, manakah media atau aplikasi penunjang } \\
\text { belajar dari rumah (school from home) yang sudah pernah Anda } \\
\text { dengar? (Jawaban boleh lebih dari satu) }\end{array}$ \\
\hline 4. & $\begin{array}{l}\text { Di masa pandemi ini, apakah media yang Anda gunakan untuk } \\
\text { memberikan materi dan tugas untuk dipelajari dan dikerjakan di } \\
\text { rumah kepada siswa/siswi didik Anda? (Jawaban boleh lebih dari } \\
\text { satu) }\end{array}$ \\
\hline 5. & Apakah Anda sudah pernah mendengar tentang Google Classroom? \\
\hline 6. & $\begin{array}{l}\text { Apakah menurut Anda aplikasi seperti Google Classroom diperlukan } \\
\text { untuk menunjang proses belajar mengajar secara online? }\end{array}$ \\
\hline 7. & $\begin{array}{l}\text { Apakah Anda sudah pernah menggunakan Google Classroom untuk } \\
\text { menunjang pengajaran secara online? }\end{array}$ \\
\hline 8. & $\begin{array}{l}\text { Apakah Anda sering mengalami kesulitan dalam menggunakan } \\
\text { Google Classroom? }\end{array}$ \\
\hline
\end{tabular}

Angket pretest menggunakan google form dalam pengerjaannya. Jadi dari hasil pretest yang dilakukan pada 12 orang guru, karena pada saat pelatihan tidak semua guru dapat mengikuti pelatihan didapatkan hasil bahwa hampir semua guru dalam melakukan pembelajaran secara daring menggunakan media sosial yaitu whatsapp atau wa. Hal tersebut dapat dilihat dari hasil angket pada gambar 5. 


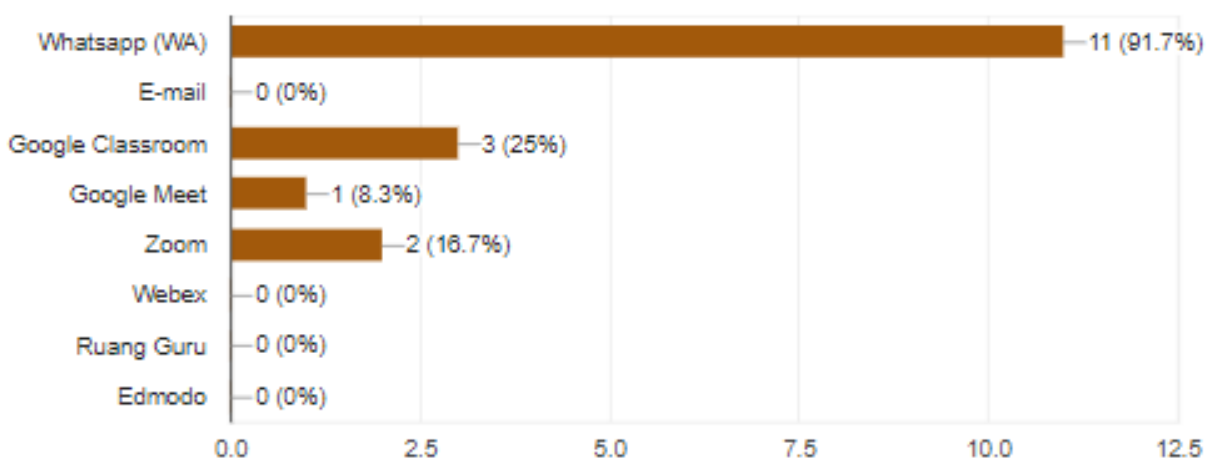

Gambar 5. Hasil pretest pertanyaan nomor 4

Selain itu ada 66,7 \% menyatakan bahwa belum pernah sama sekali menggunakan google classroom. Jadi dengan adanya pelatihan ini diharapkan para guru lebih mengenal google classroom dan dapat memudahkan dalam melakukan pembelajaran secara daring.

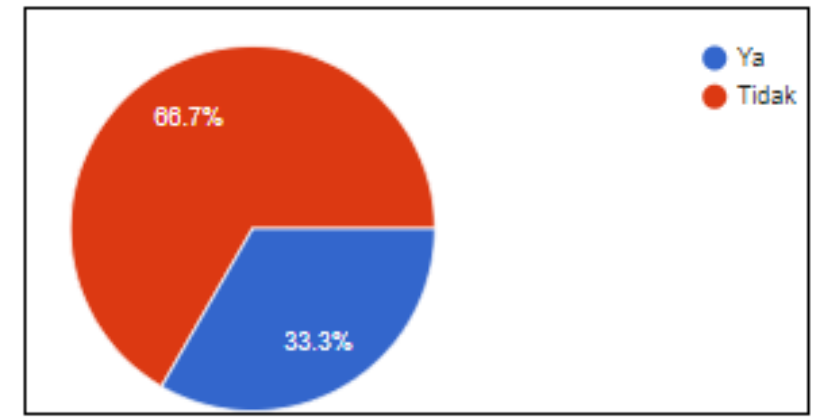

Gambar 6. Hasil pretest dari pertanyaan nomor 7

Dari hasil angket pretest tersebut dapat disimpulkan bahwa sebagian besar guru SD 2 Kawan pada saat melakukan pembelajaran secara daring masih menggunakan media sosial WA untuk proses pengiriman materi dan tugas. Selain itu lebih dari setengah dari jumlah guru masih belum memahami dan mengenal google classroom. Setelah kegiatan pelatihan dilakukan maka setiap peserta pelatihan diberikan angket posttest untuk mengetahui sejauh mana pemahaman mereka tentang pelatihan yang sudah diberikan. Pada tabel 2 adalah pertanyaan yang digunakan untuk mengukur tingkat perkembangan guru setelah mendapat pelatihan.

Tabel 2. Tabel pertanyaan posttest

\begin{tabular}{|c|l|}
\hline No. & \multicolumn{1}{|c|}{ Pertanyaan } \\
\hline 1. & $\begin{array}{l}\text { Setelah mendapatkan materi mengenai Google Classroom hari ini, } \\
\text { menurut Anda, apakah Google Classroom dapat dimanfaatkan untuk } \\
\text { menunjang pengajaran kepada siswa/siswi didik Anda? }\end{array}$ \\
\hline 2. & $\begin{array}{l}\text { Setelah mengikuti pelatihan hari ini, apakah Anda memahami apa saja } \\
\text { fitur-fitur dan kegunaan dari Google Classroom? }\end{array}$ \\
\hline 3. & $\begin{array}{l}\text { Setelah mengikuti pelatihan hari ini, apakah Anda memahami cara } \\
\text { menggunakan Google Classroom untuk memberikan materi dan tugas } \\
\text { kepada siswa/siswi? }\end{array}$ \\
\hline 4. & $\begin{array}{l}\text { Menurut Anda, apakah Google Classroom dapat membantu pekerjaan } \\
\text { Anda sebagai tenaga pendidik (Guru) dalam memberikan pengajaran } \\
\text { secara online di masa pandemi ini? }\end{array}$ \\
\hline
\end{tabular}


5. $\quad$ Setelah mengikuti pelatihan hari ini, apakah Anda akan memanfaatkan dan menggunakan Google Classroom untuk menunjang proses belajar mengajar nantinya?

Angket posttest menggunakan google form dalam pengerjaannya. Dari hasil angket posttest didapatkan hasil bahwa semua guru sangat yakin bahwa google classroom dapat membantu menunjang pembelajaran secara daring. Hal tersebut dapat dilihat dari hasil angket posttest yang menunjukkan $100 \%$ guru menyatakan bahwa google classroom sangat membantu menunjang pembelajaran secara daring. Adapun hasil angket dapat dilihat pada gambar 7 .

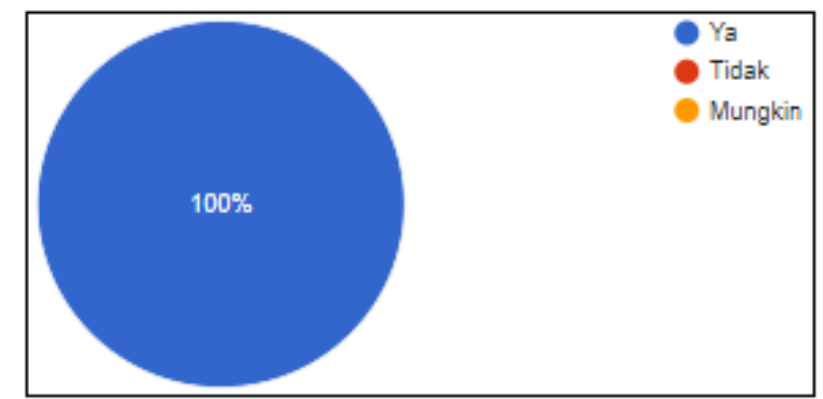

Gambar 7. Hasil angket dari pertanyaan nomor 1

Selain itu terdapat 8,3\% guru sangat memahami, 41,7 \% memahami dan $50 \%$ cukup memahami fitur-fitur yang terdapat pada google classroom. Dan tidak ada guru yang kurang memahami fitur-fitur google classroom, apalagi tidak memahami. Ini berarti setelah pelatihan ini dilakukan, berarti semua guru sudah dapat memahami semua materi yang diberikan. Hasil angket dari pertanyaan ketiga tersebut dapat dilihat pada gambar 8 .

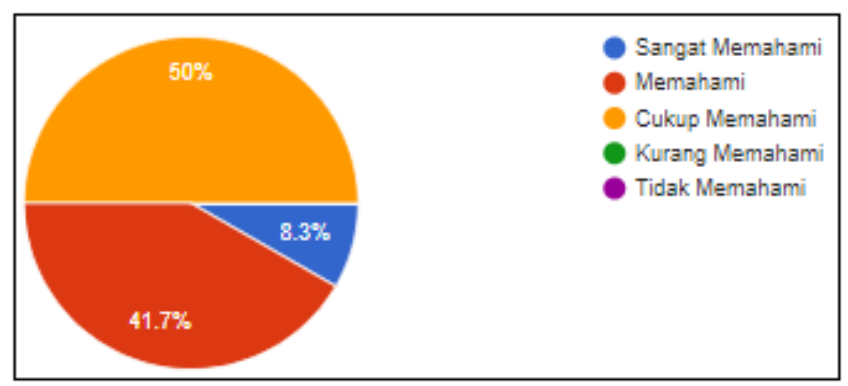

Gambar 8. Hasil angket dari pertanyaan nomor 3

\section{KESIMPULAN}

Berdasarkan hasil kegiatan dan analisis dari angket yang dilakukan, maka dapat ditarik ksimpulan sebagai berikut:

1. Pelatihan yang telah dilakukan memberikan pengetahuan baru tentang penggunaan google classroom dan pembuatan video pembelajaran untuk menunjang pengajaran secara daring bagi guru SD 2 Kawan.

2. Hasil analisis dari angket pretest dan posttest menunjukkan bahwa hampir sebagian besar guru sebelumnya menggunakan media social WA sebagai media yang digunakan untuk pembelajaran secara daring. Namun setelah mendapatkan pelatihan sebagian besar guru akan berpindah ke media google classroom karena $100 \%$ guru menyatakan 
bahwa google classroom sangat membantu dalam menunjang pembelajaran secara daring.

3. Analisa lainnya yaitu terdapat $8,3 \%$ guru sangat memahami, $41,7 \%$ memahami dan $50 \%$ cukup memahami fitur-fitur yang terdapat pada google classroom dimana artinya sebagian besar guru sudah memahami pemakaian google classroom. Dari hasil tersebut menunjukkan bahwa pelatihan yang dilakukan medapat respon baik dari pihak sekolah SDN 2 Kawan serta pelatihan yangdilakukan akan diterapkan untuk menunjang pembelajaran daring.

\section{SARAN}

Berdasarkan hasil kegiatan pelatihan yang telah dilakukan, perlu dirasa untuk dilakukan pengembangan dari kegiatan yang telah dilakukan, yaitu:

1. Diharapkan para guru menerapkan ilmu yang telah didapatkan selama pelatihan kepada anak didik.

2. Untuk selanjutnya diharapkan ada kerja sama kembali dengan pihak SDN 2 Kawan untuk materi lanjutan dari materi pelatihan sebelumnya.

3. Menjalin kerjasama antara STMIK STIKOM Indonesia dengan lembaga pendidikan lainnya untuk membantu pengembangan sistem pendidikan yang ada.

\section{UCAPAN TERIMA KASIH}

Ucapan terima kasih yang sebesar-besarnya diucapkan kepada STMIK STIKOM Indonesia, LPPM STMIK STIKOM Indonesia yang telah memberikan fasilitas dan bantuan dana sehingga pengabdian kepada masyarakat ini dapat berjalan dengan lancar, serta tidak lupa kepada seluruh pihak di Sekolah Dasar Negeri 2 Kawan Bangli, Kabupaten Bangli.

\section{DAFTAR PUSTAKA}

Bungin Burhan. (2011). Metode Penelitian Kuntitatif : Komunikasi, Ekonomi, dan Kebijakan Publik serta IImu-ilmu lainnya, Edisi Kedua (2nd ed.). Jakarta: Kencana Prenama Media Group

Minardi, J. and Akbar, A. S. (2020) 'Pelatihan Pengembangan Media Pembelajaran Interaktif dengan Power Point untuk Peningkatan Kompetensi Guru SD', E-Dimas: Jurnal Pengabdian Kepada Masyarakat, 11(1), pp. 96-100. doi: 10.26877/e-dimas.v11i1.2747.

Handayani, F., Sepyanda, M., Dwiputri, R., Riyen Permata, \& Zulfariati. (2021). Optimalisasi Penggunaan WhatsApp Group Sebagai Sarana Komunikasi dan Media Pembelajaran Online Selama Masa Pandemi COVID-19 bagi Guru SD Negeri 10 Pianggu. PUAN INDONESIA, 3(1), 19-28. https://doi.org/10.37296/jpi.v3i1.53

Pratama, D.॰; H. S. (2016) Analisis Pengaruh Pemanfaatan Google Classroom Terhadap Efisiensi Pada STMIK XYZ (Vol. 16, pp. 251 254 ). Vol. 16, pp. $251 \leq 254$. Retrieved from http://ci.nii.ac.jp/naid/40020776815/

Setiorini, I. L. (2018) 'Penyuluhan dan Pelatihan Membuat Media Pembelajaran Animasi Flash Kepada Guru Sekolah Dasar di Kecamatan Panarukan Kabupaten Situbondo', Integritas, 2(2), pp. 91-100. doi: 10.36841/integritas.v2i2.251. 
Siyoto, S. and Sodik, M. A. (2015) DASAR METODOLOGI PENELITIAN. Yogyakarta: Literasi Media Publishing. 